\title{
IRE1 KNOCKDOWN MODIFIES HYPOXIC REGULATION OF CATHEPSINS AND LONP1 GENES EXPRESSION IN U87 GLIOMA CELLS
}

\author{
O. H. MINCHENKO', O. O. RIABOVOL ${ }^{1}$, O. V. HALKIN", \\ D. O. MINCHENKO ${ }^{1,2}$, O. O. RATUSHNA ${ }^{1}$ \\ ${ }^{1}$ Palladin Institute of Biochemistry, National Academy of Sciences of Ukraine, Kyiv; \\ e-mail: ominchenko@yahoo.com; \\ ${ }^{2}$ Bohomolets National Medical University, Kyiv, Ukraine
}

\begin{abstract}
We have studied the effect of hypoxia on the expression of genes encoding for LONP1/PRSS15 and cathepsins in U87 glioma cells in relation to inhibition of inositol requiring enzyme-1 (IRE1). It was shown that hypoxia up-regulated the expression of CTSA, CTSB, CTSD, CTSF, CTSK, and LONP1 genes and downregulated the expression of CTSC, CTSL, CTSO, and CTSS genes in control glioma cells (transfected by empty vector). Inhibition of IRE1 signaling enzyme function in these glioma cells modified effect of hypoxia on the expression of most studied genes: eliminated the effect of hypoxia on CTSA, and LONP1 genes, introduced reverse changes on CTSD and CTSS genes, reduced - on CTSF and CTSK genes, and enhanced - on CTSB and CTSL genes. Therefore, hypoxia affected the expression level of most studied genes in relation to the functional activity of IREI enzyme, a central mediator of endoplasmic reticulum stress, which control cell proliferation and tumor growth.
\end{abstract}

Key words: hypoxia, mRNA expression, cathepsins, LONP1, IRE1 inhibition, U87 glioma cells.

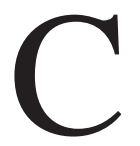

athepsins are a group of lysosomal proteases that have a key role in cellular and extracellular protein turnover as well as multiple roles in cancer and autophagy [1-3]. Cathepsin A (CTSA), also known as chaperone protective protein and protective protein for $\beta$-galactosidase, is a lysosomal carboxypeptidase present at the cell surface, endoplasmic reticulum, nucleus and secreted outside the cell, which appears to be essential for both the activity of beta-galactosidase and neuraminidase, it associates with these enzymes and performs a protective function necessary for their stability and activity and involved in tumor progression and metastasis by degrading the extracellular matrix $[3,4]$. Cathepsin A plays a significant role in the processing of endogenous bioactive peptides and is also involved in inhibition of chaperon-mediated autophagy through proteolytic processing of LAMP-2A [1, 2]. Recently it was shown that overexpression of CTSA associates with the cellular oxidative stress response [5].
CTSB is a lysosomal cysteine proteinase, which is also present at the cell surface, nucleus and mitochondrion, implicated in tumor invasion and metastasis; toll-like receptor signaling pathway [6]. Recently it was shown that inhibition of cathepsin $\mathrm{B}$ activity by clioquinol-ruthenium complex impairs tumor cell invasion [7]. Extracellular matrix remodeling by cell adhesion-related processes is critical for proliferation and tissue homeostasis and the actin-binding protein, filamin $\mathrm{A}$, regulates the organization and remodeling of the pericellular collagen matrix through its effects on degradation pathways, particularly MMP-9 and cathepsin B, which is necessary for intracellular collagen digestion [8]. Huber et al. [9] have shown that the urokinase plasminogen activator receptor strongly interacts with cysteine-rich angiogenic inducer 61 (CYR61) and the Y-box-binding protein 1(YB-1) in the triple-negative breast cancer and that both interactors significantly correlated with the expression levels of cathepsin B, c-MET and the tumor grade. In addition, expres-

(C) 2017 Minchenko O. H. et al. This is an open-access article distributed under the terms of the Creative Commons Attribution License, which permits unrestricted use, distribution, and reproduction in any medium, provided the original author and source are credited. 
sion levels of CYR61 significantly correlated with cathepsin D [9]. Moreover, myeloid-derived suppressor cells are immune suppressive cells that are hallmarks of human cancer and apoptosis pathways play a key role in homeostasis of these cells through CTSB and CTSD [10]. Cathepsin B also participates in autophagy, which mediates tumor suppression via cellular senescence, particularly in TGF- $\beta$-induced autophagy [11-13].

Increased tissue activity of cathepsin $\mathrm{C}$ can be observed in many pathological conditions [4]. It is associated with an enhanced degradation of glycosaminoglycans, proteoglycans, and glycoproteins, and results in their decreased tissue content. Cathepsin $\mathrm{C}$ releases the glycosidases from complexes formed with cathepsin $\mathrm{A}$, and reinstates their activity [4]. Furthermore, CTSB, CTSC, and CTSD are increased in numerous tumors $[14,15]$. Thus, human telomerase reverse transcriptase (hTERT) overexpression is responsible for the upregulation of the cysteine protease cathepsin D by regulating EGR-1 to activate invasiveness in cancer progression [15]. It is interesting to note that matrix-metalloproteinase-9 is cleaved and activated by cathepsin K [16]. Moreover, almost identical substrate specificities were determined for cysteine cathepsins $\mathrm{K}, \mathrm{L}$ and $\mathrm{S}$ [17]. Cathepsin $\mathrm{S}$ also has relation to regulation of autophagy [18].

Mitochondria play an important role in tumor progression but its functional activity is reprogrammed in cancers [19-21]. The mitochondrial Lon peptidase 1 (LONP1, also known as serine protease 15; PRSS15), is a mitochondrial matrix protein that belongs to the Lon family of ATP-dependent proteases and mediates the selective degradation of misfolded, unassembled or oxidative damaged polypeptides as well as certain short-lived regulatory proteins in the mitochondrial matrix, but not aggregated proteins [19, 22]. LONP1 may also have a chaperone function in the assembly of inner membrane protein complexes, and participate in the regulation of mitochondrial gene expression and maintenance of the integrity of the mitochondrial genome [23]. Lon peptidase 1 can be included in the growing class of proteins that are not responsible for oncogenic transformation, but that are essential for survival and proliferation of cancer cells, because it is a key enzyme controlling mitochondrial bioenergetics in cancer $[23,24]$. Therefore, LONP1 is an essential protein for life and that it also performs a critical function in tumorigenesis by regulating the bioenergetics of cancer cells as a central regulator of mitochondrial activity in oncogenesis [33]. Recently it was shown that inhibition of LONP1 by the anticancer molecule triterpenoid alters mitochondria and is associated with to cell death in RKO human colon cancer cells [20]. LONP1 expression is induced by various stimuli, including hypoxia and reactive oxygen species, and provides protection against cell stress [25]. Furthermore, down-regulation of this enzyme is associated with ageing and with cell senescence, while up-regulation is observed in tumor cells, and is correlated with a more aggressive phenotype of cancer [25]. Consequently, the mitochondrial Lon peptidase 1 is at the crossroads of oxidative stress, ageing and cancer. Goo et al. [26] have shown that mitochondrial proteins, LONP1 and prohibitin, are overexpressed in HTRA2(-/-) mouse embryonic fibroblast cells and HTRA2 knock-down HEK293T cells, indicating that mitochondrial HTRA2 (hightemperature requirement A serine peptidase 2) might be an upstream regulator of mitochondrial homeostasis.

The unfolded protein response/endoplasmic reticulum stress is responsible for enhanced cancer cell proliferation and knockdown of IRE1, a major signaling pathway of endoplasmic reticulum stress, by a dominant-negative construct of IRE1 (dnIRE) resulted in a significant anti-proliferative effect on glioma growth [27-29]. The rapid growth of solid tumors generates micro-environmental changes in association with hypoxia, nutrient deprivation and acidosis, which promote neovascularisation, cell survival and proliferation [30-32]. The activation of endoplasmic reticulum stress is indispensable for tumor growth as it facilitates adaptation to stressful environmental conditions [33]. IRE1 is the most evolutionary conserved sensor that responds to protein misfolding with a highly tuned program aimed to either resolve the stress or direct the cell towards apoptosis in case stress becomes too severe, which makes it a key regulator of cell life and death processes [28, 33]. Recently, we have shown that glucose deprivation affects the expression of proliferation related genes in U87 glioma cells and that IRE1 knockdown modifies glucose deprivation effects on these genes expression possibly contributing to suppression of glioma cells proliferation [34].

Malignant gliomas are highly aggressive tumors with very poor prognosis and to date there is no efficient treatment available. The moderate efficacy of conventional clinical approaches therefore 
underlines the need for new therapeutic strategies. Glucose is important substrate for glycolysis, which is important to glioma development and a more agressive behaviour [35]. A better knowledge of tumor responses to glucose deprivation condition is required to elaborate therapeutical strategies of cell sensibilization, based on the blockade of survival mechanisms [36, 37].

The aim of this study was investigation of the effect of hypoxia on the expression of LONP1/ PRSS15 and a subset of cathepsins in glioma cells in relation to inhibition of IRE1, a major signaling enzyme of endoplasmic reticulum stress, with hopes of elucidating its mechanistic part in the development and progression of glioma and the contribution to unfolding protein response.

\section{Materials and Methods}

Cell lines and culture conditions. In this study we used two sublines of U87 glioma cells, which are growing in high glucose (4.5 g/l) Dulbecco's modified Eagle's minimum essential medium (DMEM; Gibco, Invitrogen, USA) supplemented with glutamine (2 mM), 10\% fetal bovine serum (EquitechBio, Inc., USA), streptomycin (0.1 mg/ml; Gibco) and penicillin (100 units/ml; Gibco) at $37^{\circ} \mathrm{C}$ in a $5 \%$ $\mathrm{CO}_{2}$ incubator. One subline was obtained by selection of stable transfected clones with overexpression of vector (pcDNA3.1), which was used for creation of dominant-negative constructs (dnIRE1). This untreated subline of glioma cells (control glioma cells) was used as control 1 in the study of hypoxia effects on the expression level of $L O N P 1, C T S A, C T S B$, CTSC, CTSD, CTSF, CTSK, CTSL, CTSO, and CTSS genes. The second subline was obtained by selection of stable transfected clones with overexpression of dnIRE1 and has suppressed both protein kinase and endoribonuclease activities of this bifunctional sensing and signaling enzyme of endoplasmic reticulum stress. The expression level of studied nuclear genes which encoded mitochondrial proteins in these cells was compared with cells, transfected by vector (control 1). The subline, which overexpresses dnIRE1, was also used as control 2 for investigation the effect of hypoxia condition on the expression level of studied in cells with inhibited signaling enzyme IRE1 function. Clones were received by selection at $0.8 \mathrm{mg} / \mathrm{ml}$ geneticin (G418) and grown in the presence of this antibiotic at lower concentration $(0.4 \mathrm{mg} /$ $\mathrm{ml})$.

In experiments with hypoxia culture plates with complete DMEM were exposed in a special chamber with 3\% oxygen, 92\% nitrogen, and 5\% carbon dioxide for 16 hrs.

The suppression level of IRE1 both enzymatic activity in glioma cells that overexpress a dominantnegative construct of inositol requiring enzyme-1 was estimated previously [27, 38] by determining the phosphorylation of IRE1 and the expression level of XBP1 alternative splice variant (XBP1s), a key transcription factor in IRE1 signaling, using cells treated by tunicamycin $(0.01 \mathrm{mg} / \mathrm{ml}$ during 2 hrs). Moreover, the proliferation rate of glioma cells with mutated IRE1 is decreased 2 fold [27, 38]. Thus, the blockade of both kinase and endoribonuclease activity of signaling enzyme IRE1 has a significant effect on proliferation rate of glioma cells.

$R N A$ isolation. Total RNA was extracted from glioma cells as previously described [38]. The RNA pellets were washed with 75\% ethanol and dissolved in nuclease-free water. For additional purification RNA samples were re-precipitated with 95\% ethanol and re-dissolved again in nuclease-free water. RNA concentration and spectral characteristics were measured using NanoDrop Spectrophotometer.

Reverse transcription and quantitative PCR analysis. QuaniTect Reverse Transcription Kit (QIAGEN, Germany) and Thermo Scientific Verso cDNA Synthesis Kit (Germany) were used for cDNA synthesis according to manufacturer's protocols. The expression level of LONP1, CTSA, CTSB, CTSC, CTSD, CTSF, CTSK, CTSL, CTSO, and CTSS mRNA were measured in glioma cell line U87 and its subline (clone 1C5) by real-time quantitative polymerase chain reaction using "RotorGene RG-3000" qPCR (Corbett Research, Germany), "7500 HT Fast Real-Time PCR System” (Applied Biosystems) or “Mx 3000P QPCR” (Stratagene, USA) and Absolute qPCR SYBRGreen Mix (Thermo Fisher Scientific, ABgene House, Epsom, Surrey, UK). Polymerase chain reaction was performed in triplicate. The amplification of cDNA of the mitochondrial lon peptidase 1 (LONP1; EC_number ="3.4.21.53"), also known as hLON ATP-dependent protease and PRSS15 (protease, serine, 15), was performed using forward primer ( $5^{\prime}-$ ATCTACCTGAGCGACATGGG-3') and reverse primer (5'-TTACGGTGGGTCTGCTTGAT-3'). These oligonucleotides correspond to sequences 1111-1130 and 1304-1285 of human LONP1 cDNA (GenBank accession number NM_004793). The size of amplified fragment is 194 bp. For amplification of the cathepsin A (CTSA; EC_number="3.4.16.5), also known as chaperone 
protective protein and carboxypeptidase C, cDNA we used next primers: forward 5'-CAGCTGCTTCCACCTACCTC $-3^{\prime}$ and reverse 5'-CTTCTGGTTGAGGGAATCCA-3'. The nucleotide sequences of these primers correspond to sequences 1432-1451 and 1682-1663 of human CTSA cDNA (GenBank accession number NM_000308). The size of amplified fragment is $251 \mathrm{bp}$. The amplification of cDNA of the cathepsin B (CTSB; EC_number="3.4.22.1") was performed using forward primer $\left(5^{\prime}-\mathrm{CAAGC}-\right.$ CACCCCAGAGAGTTA- $3^{\prime}$ ) and reverse primer (5'-TAGAGGCCACCAGAAACCAG-3'). These oligonucleotides correspond to sequences 360-379 and 680-661 of human CTSB cDNA (GenBank accession number NM_001908). The size of amplified fragment is $321 \mathrm{bp}$. For amplification of the CTSC (EC_number="3.4.14.1) cDNA we used next primers: forward 5'-TCAGACCCCAATCCTAAGCC $-3^{\prime}$ and reverse $5^{\prime}-$ GCATGGAGAATCAGTGCCTG $-3^{\prime}$. The nucleotide sequences of these primers correspond to sequences 949-968 and 1108-1089 of human CTSC cDNA (GenBank accession number NM_001814). The size of amplified fragment is $160 \mathrm{bp}$. The amplification of cDNA for the CTSD (EC_number="3.4.23.5") was performed using forward primer (5'-CAAGTTCGATGGCATCCTGG-3') and reverse primer (5'-CGGGTGACATTCAGGTAGGA-3'). These oligonucleotides correspond to sequences 712-731 and 930-911 of human CTSD cDNA (GenBank accession number NM_001909). The size of amplified fragment is $219 \mathrm{bp}$. For amplification of the CTSF (EC_number="3.4.22.41) cDNA we used next primers: forward 5'-AGGAGCTCTTGGACTGTGAC- $3^{\prime}$ and reverse 5'-TAGACCTTGGCCTTCTCTGC-3'. The nucleotide sequences of these primers correspond to sequences 1052-1071 and 1217-1198 of human CTSF cDNA (GenBank accession number NM_003793). The size of amplified fragment is $166 \mathrm{bp}$. The amplification of the CTSK (EC_number="3.4.22.38) cDNA was performed using forward primer $\left(5^{\prime}\right.$-GCTCAAGGTTCTGCTGCTAC- $\left.3^{\prime}\right)$ and reverse primer (5'-TCTTCACTGGTCATGTCCCC $-3^{\prime}$ ). These oligonucleotides correspond to sequences 238-257 and 483-464 of human CTSK cDNA (GenBank accession number NM_000396). The size of amplified fragment is 246 bp. For amplification of the CTSL (EC_number="3.4.22.15) cDNA we used next primers: forward 5'-ACAGCTTCACAATGGCCATG-3' and reverse 5'-AAGCCCAACAAGAACCACAC-3'. The nucleotide sequences of these primers cor- respond to sequences $562-581$ and $717-698$ of human CTSL cDNA (GenBank accession number NM_001912). The size of amplified fragment is $210 \mathrm{bp}$. The amplification of the CTSO (EC_number="3.4.22.42) cDNA was performed using forward primer (5'-ATTATGGCTGCAATGGAGGC-3') and reverse primer (5'-GGGCCAAAGGTAAGAAGTGC- 3 '). These oligonucleotides correspond to sequences $549-568$ and 768-749 of human CTSO cDNA (GenBank accession number NM_001334). The size of amplified fragment is $220 \mathrm{bp}$. For amplification of the CTSS (EC_number="3.4.22.27) cDNA we used next primers: forward 5'-AACAAGGGCATCGACTCAGA-3' and reverse 5'-AAGAAAGAAGGATGACGCGC-3'. The nucleotide sequences of these primers correspond to sequences 844-863 and 468-449 of human CTSS cDNA (GenBank accession number NM_004079). The size of amplified fragment is $197 \mathrm{bp}$. The amplification of the beta-actin (ACTB) cDNA was performed using forward 5'-GGACTTCGAGCAAGAGATGG-3' and reverse - 5'-AGCACTGTGTTGGCGTACAG-3' primers. These primers nucleotide sequences correspond to 747-766 and 980-961 of human ACTB cDNA (GenBank accession number NM_001101). The size of amplified fragment is $234 \mathrm{bp}$. The expression of $\beta$-actin mRNA was used as control of analyzed RNA quantity. The primers were received from Sigma-Aldrich (St. Louis, MO, USA). The quality of amplification products was analyzed by melting curves and by electrophoresis using $2 \%$ agarose gel. An analysis of quantitative PCR was performed using special computer program Differential Expression Calculator. The values of LONP1, CTSA, CTSB, CTSC, CTSD, CTSF, CTSK, CTSL, CTSO, and CTSS mRNA expressions were normalized to the expression of $\beta$-actin mRNA and represented as percent of control 1 (100\%).

Statistical analysis. All values are expressed as mean \pm SEM from triplicate measurements performed in 4 independent experiments. Statistical analysis was performed according to Student's $t$-test using Excel program as described previously [40].

\section{Results and Discussion}

We have studied the effect of hypoxia on the expression of genes encoding LONP1, CTSA, CTSB, CTSC, CTSD, CTSF, CTSK, CTSL, CTSO, and CTSS proteins in two sublines of U87 glioma cells in relation to inhibition of IRE1 signaling enzyme, which is a major component of the unfolded pro- 
tein response. It was shown that in control glioma cells (transfected by empty vector) hypoxia significantly up-regulates $(+33 \%)$ the expression of gene for cathepsin A (Fig. 1). Moreover, in cells without functional activity of IRE1 signaling enzyme the expression of this gene was not changed by hypoxia. Furthermore, inhibition of IRE1 signaling enzyme function in U87 glioma cells by dnIRE1 leads to significant up-regulation of CTSA gene expression $(+111 \%)$ upon normoxic condition in comparison with the control glioma cells (Fig. 1).

As shown in Fig. 2, the expression level of $C T S B$ gene is increased in both control glioma cells and cells with suppressed activity of IRE1 signaling enzyme upon hypoxia ( +25 and $+44 \%$, correspondingly). Thus, inhibition of IRE1 enhances the effect of hypoxia on this gene expression. We also studied the effect of IRE1 inhibition on the expression of

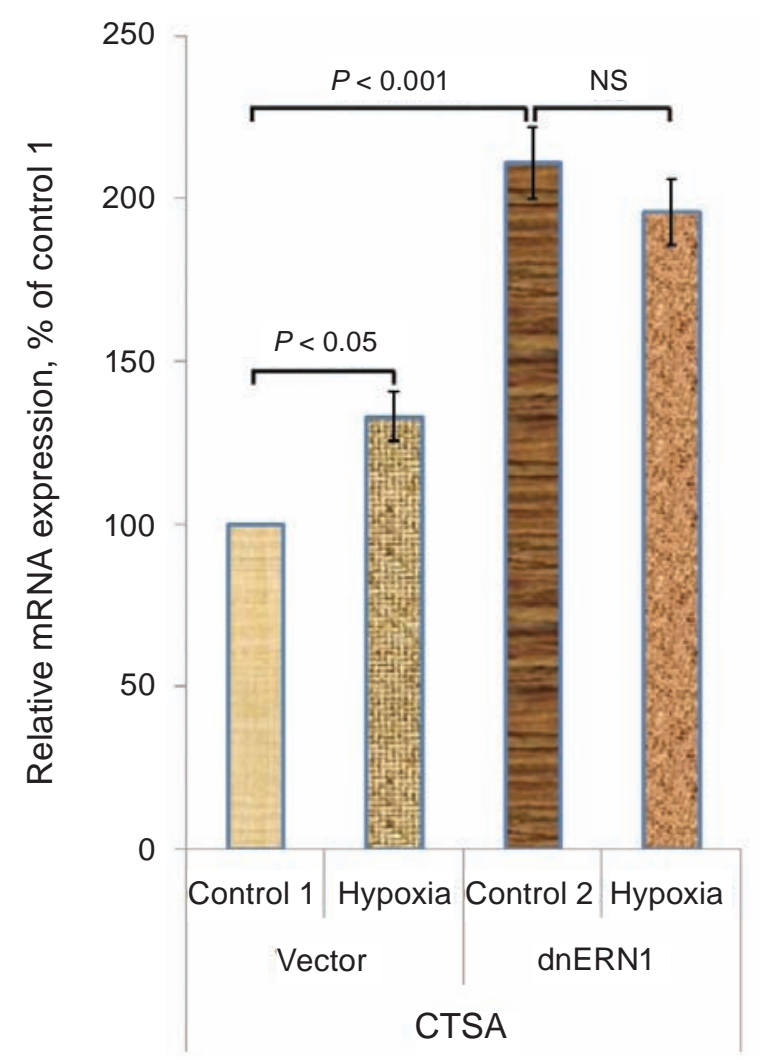

Fig. 1. Effect of hypoxia (3\% oxygen - 16 hrs) on the expression level of cathepsin A (CTSA) mRNA in control U87 glioma cells stable transfected with vector (Vector) and cells with inhibited function of signaling enzyme IRE1 (dnIREI) measured by qPCR. Values of CTSA $m R N A$ expressions were normalized to $\beta$-actin $m R N A$ and represented as percent of control 1 (100\%); mean \pm SEM; $n=4$

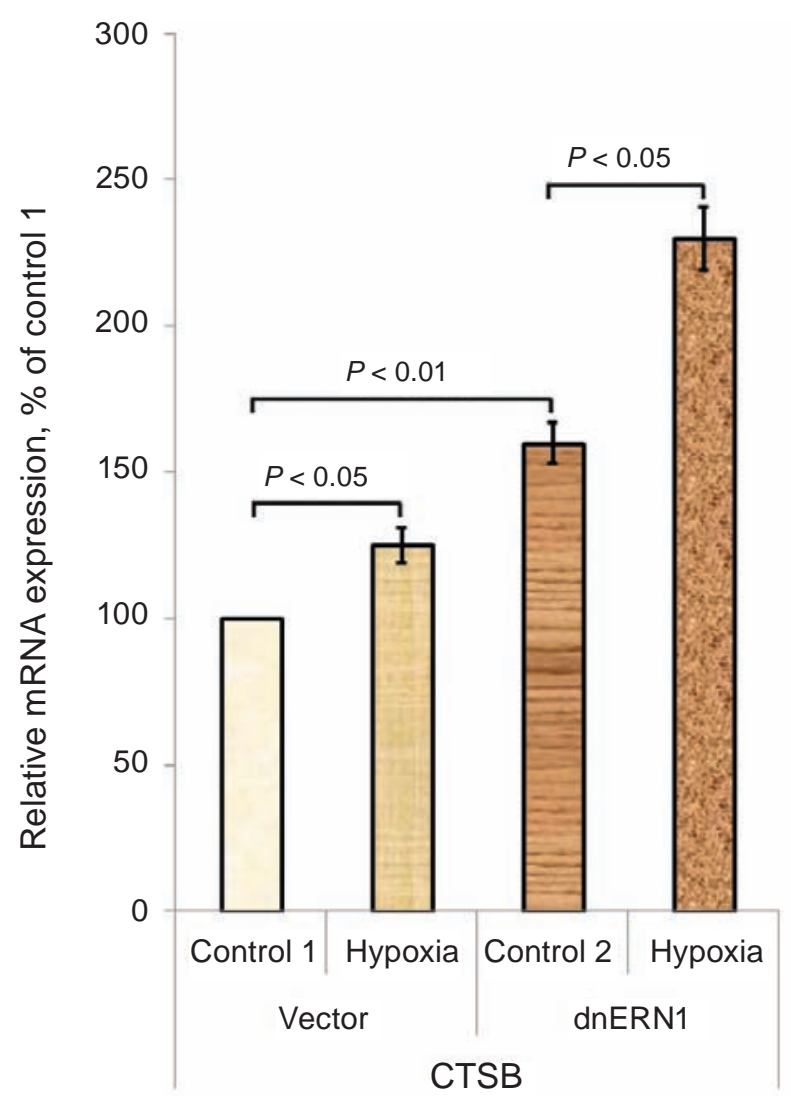

Fig. 2. Effect of hypoxia on the expression level of cathepsin B (CTSB) mRNA in control U87 glioma cells stable transfected with vector (Vector) and cells with inhibited function of signaling enzyme IRE1 (dnIRE1) measured by qPCR. Values of CTSB mRNA expressions were normalized to $\beta$-actin $m R N A$ and represented as percent of control 1 (100\%); mean \pm SEM; $n=4$

this gene in normoxic condition. It was shown that inhibition of IRE1 signaling enzyme is significantly increased (+60\%) the expression level of CTSB mRNA in glioma cells upon normoxic condition as compared to control glioma cells (Fig. 2).

Investigation of the expression of CTSC gene, which encodes cathepsin $C$ enzyme, shown that hypoxia down-regulated the expression this gene in both control U87 glioma cells and cells with inhibited IRE1 signaling enzyme function (-53 and $-54 \%$; Fig. 3). Next we studied the effect of inhibition of IRE1 signaling enzyme function on the expression of CTSC gene in normoxic condition: the level of CTSC mRNA expression is down-regulated (almost in 3 fold) in glioma cells without IRE1 enzyme function in comparison with the control glioma cells.

We next investigated the effect of hypoxia on the expression of CTSD gene in control U87 glioma 


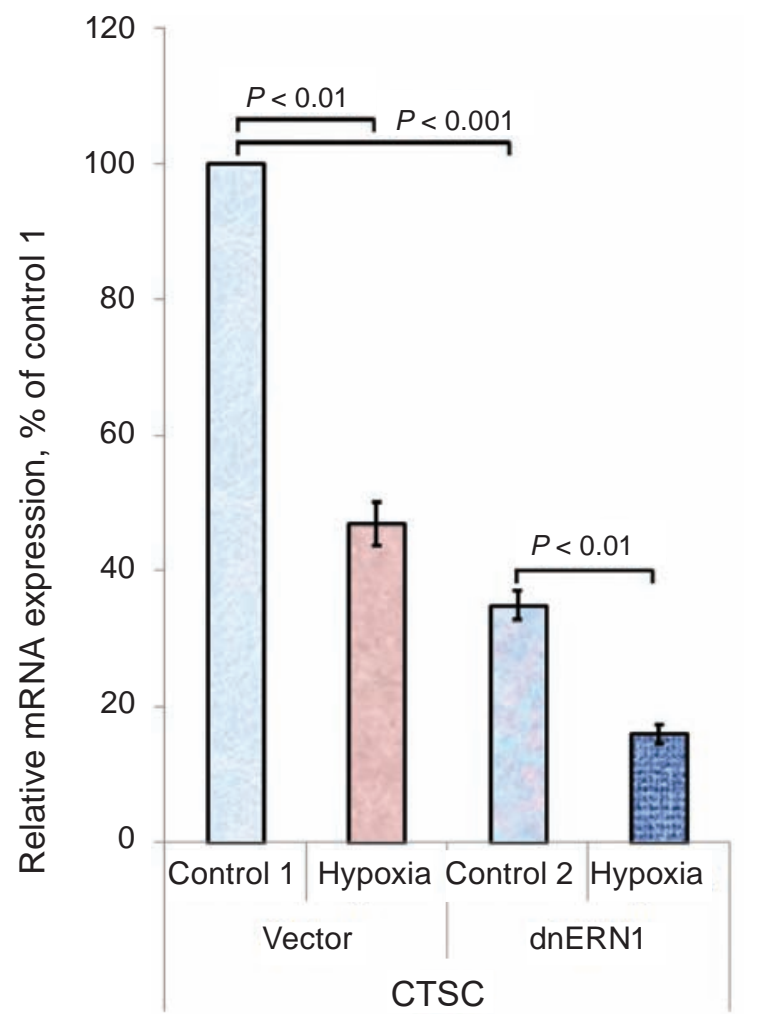

Fig. 3. Effect of hypoxia on the expression level of cathepsin C (CTSC) mRNA in control U87 glioma cells stable transfected with vector (Vector) and cells with inhibited function of signaling enzyme IREI (dnIRE1) measured by qPCR. Values of CTSC $m R N A$ expressions were normalized to $\beta$-actin $m R N A$ and represented as percent of control 1 (100\%); mean \pm $S E M ; n=4$

cells and cells with inhibited function of signaling enzyme IRE1. As shown in Fig. 4, the expression level of CTSD mRNA is up-regulated (+46\%) in control glioma cells treated by hypoxia. In cells with suppressed function of IRE1 hypoxia is also decreased the level of CTSD mRNA expression in comparison with the control 2 glioma cells (-17\%). Thus, the effect of hypoxia on this gene expression is significantly reduced in glioma cells with suppressed IRE1 function. Furthermore, the expression of this gene is strongly up-regulated in normoxic condition by inhibition of signaling enzyme IRE1 (+208\%) as compared to control glioma cells.

As shown in Fig. 5, the expression level of CTSF mRNA is increased in both control glioma cells and cells with suppressed activity of IRE1 signaling enzyme upon hypoxia (+52 and $+19 \%$, correspondingly). Thus, inhibition of IRE1 significantly reduces the effect of hypoxia on this gene expres- sion. We also studied the effect of IRE1 inhibition on the expression of CTSF gene in normoxic condition and showed that inhibition of IRE1 signaling enzyme strongly increased $(+134 \%)$ the expression level of this gene in glioma cells as compared to control glioma cells (Fig. 5).

Investigation of the expression of CTSK gene, which encodes cathepsin K enzyme, showed that hypoxia up-regulated the expression of this gene in both control U87 glioma cells and cells with inhibited IRE1 signaling enzyme function ( +43 and $+28 \%$; Fig. 6). Next we studied the effect of inhibition of IRE1 signaling enzyme function on the expression of CTSK gene in normoxic condition: the level of this mRNA expression is slightly down-regulated (-15\%) in glioma cells without IRE1 enzyme function in comparison with the control glioma cells (Fig. 6).

As shown in Fig. 7, the expression level of CTSL mRNA is decreased in both control glioma

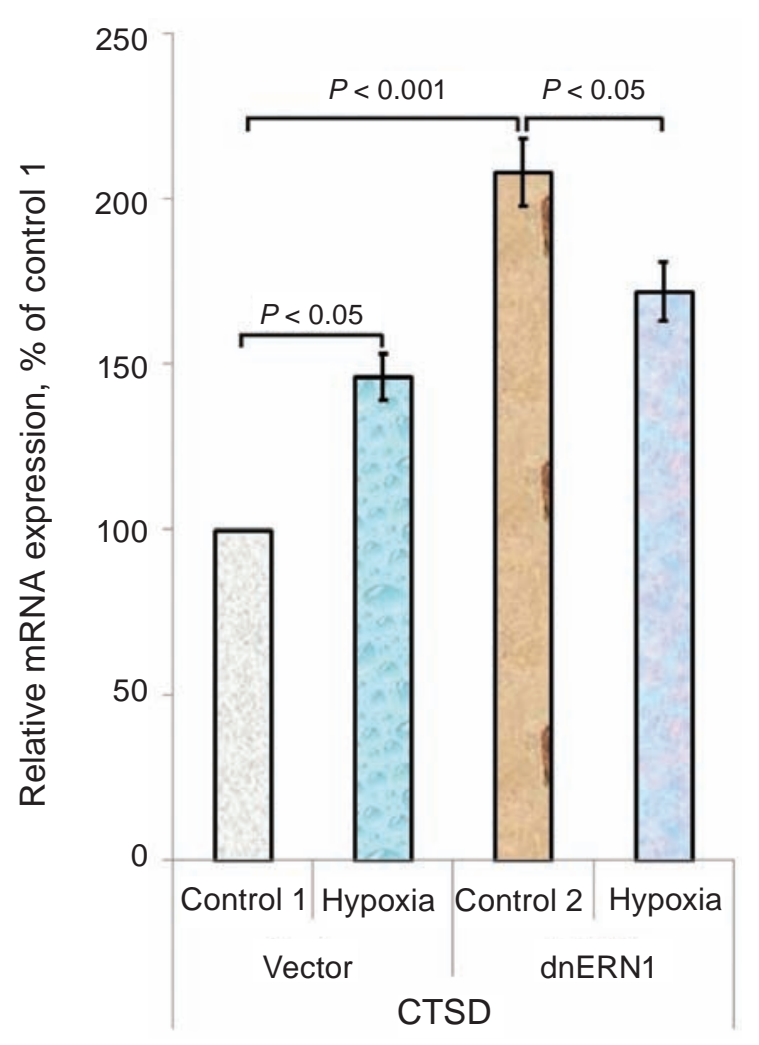

Fig. 4. Effect of hypoxia on the expression level of cathepsin D (CTSD) mRNA in control U87 glioma cells stable transfected with vector (Vector) and cells with inhibited function of signaling enzyme IREI (dnIRE1) measured by qPCR. Values of CTSD $m R N A$ expressions were normalized to $\beta$-actin $m R N A$ and represented as percent of control 1 (100\%); mean \pm SEM; $n=4$ 


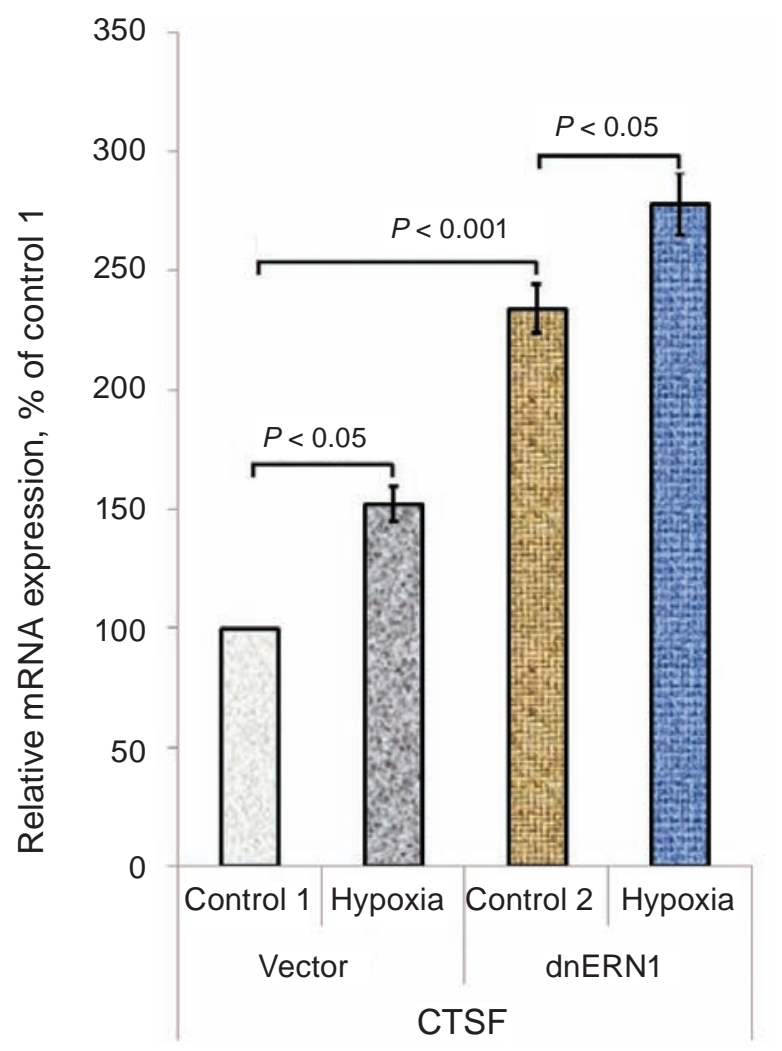

Fig. 5. Effect of hypoxia on the expression level of cathepsin F (CTSF) mRNA in control U87 glioma cells stable transfected with vector (Vector) and cells with inhibited function of signaling enzyme IRE1 (dnIRE1) measured by qPCR. Values of CTSF $m R N A$ expressions were normalized to $\beta$-actin $m R N A$ and represented as percent of control 1 (100\%); mean \pm SEM; $n=4$

cells and cells with suppressed activity of IRE1 signaling enzyme upon hypoxia (-16 and -26\%, correspondingly). Thus, inhibition of IRE1 significantly reduces the effect of hypoxia on this gene expression. We also studied the effect of IRE1 inhibition on the expression of CTSL gene in normoxic condition and it was shown that inhibition of IRE1 signaling enzyme strongly decreased (-66\%) the expression level of this gene in glioma cells as compared to control glioma cells (Fig. 7).

We next investigated the effect of hypoxia on the expression of CTSO gene in control U87 glioma cells and cells with inhibited function of signaling enzyme IRE1. As shown in Fig. 8, the expression level of CTSO mRNA is down-regulated (-33\%) in control glioma cells treated by hypoxia. In cells with suppressed function of IRE1 the hypoxia also decreased the level of CTSO mRNA expression in comparison with the control 2 glioma cells (-31\%).
Thus, the effect of hypoxia on this gene expression is significantly reduced in glioma cells with suppressed IRE1 function. Furthermore, the expression of this gene is strongly up-regulated in normoxic condition by inhibition of signaling enzyme IRE1 $(+85 \%)$ as compared to control glioma cells (Fig. 8).

Investigation of the expression of CTSS gene, which encodes cathepsin S enzyme, showed that hypoxia down-regulated the expression this gene in control U87 glioma cells and up-regulated cells with inhibited IRE1 signaling enzyme function $(-17$ and $+86 \%$; Fig. 9). Next we studied the effect of inhibition of IRE1 signaling enzyme function on the expression of CTSS gene in normoxic condition: the level of this mRNA expression is strongly down-regulated (-93\%) in glioma cells without IRE1 enzyme function in comparison with the control glioma cells (Fig. 9).

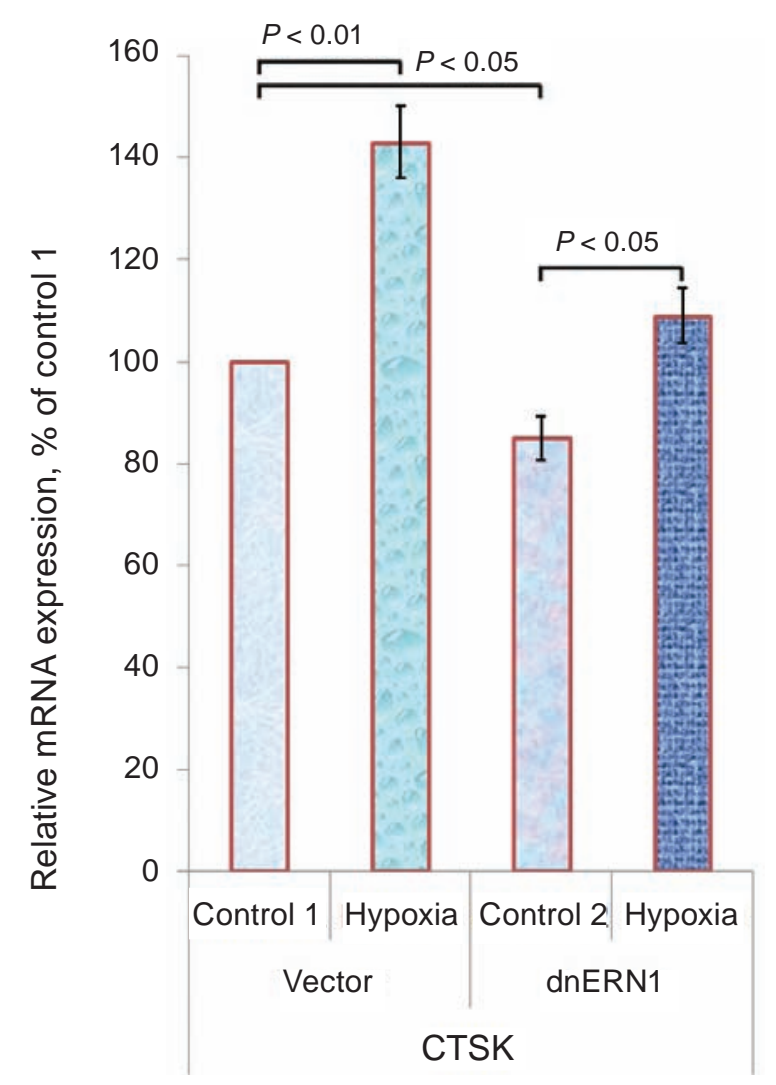

Fig. 6. Effect of hypoxia on the expression level of cathepsin K (CTSK) mRNA in control U87 glioma cells stable transfected with vector (Vector) and cells with inhibited function of signaling enzyme IREI (dnIRE1) measured by qPCR. Values of CTSK $m R N A$ expressions were normalized to $\beta$-actin $m R N A$ and represented as percent of control 1 (100\%); mean \pm SEM; $n=4$ 


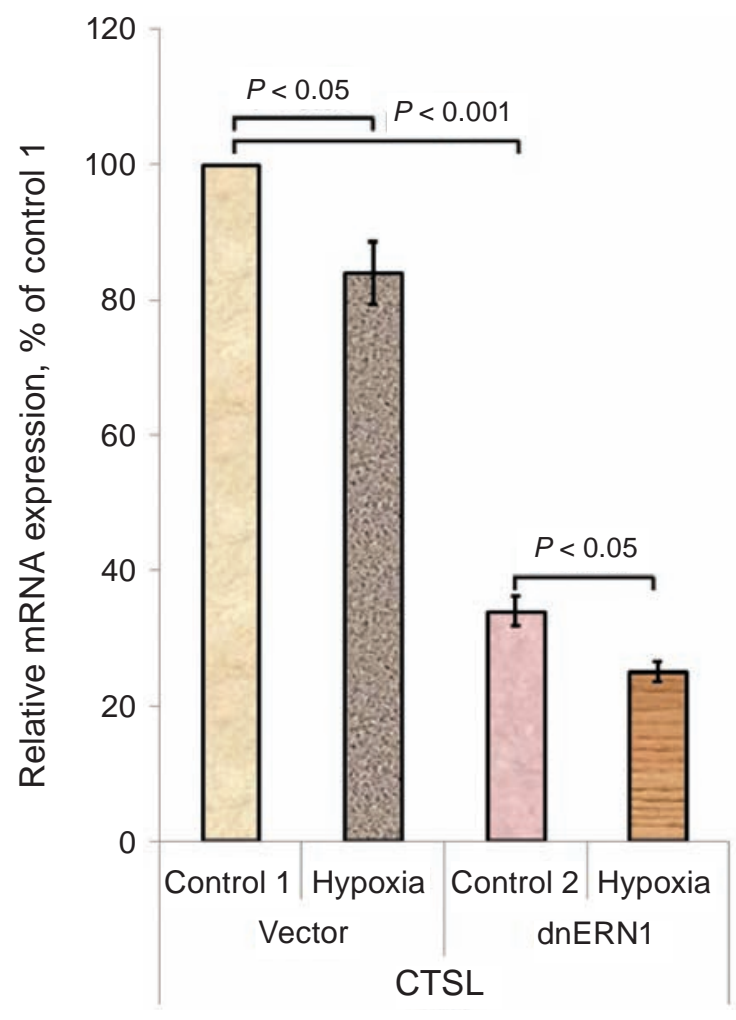

Fig. 7. Effect of hypoxia on the expression level of cathepsin L (CTSL) mRNA in control U87 glioma cells stable transfected with vector (Vector) and cells with inhibited function of signaling enzyme IRE1 (dnIRE1) measured by qPCR. Values of CTSL $m R N A$ expressions were normalized to $\beta$-actin $m R N A$ and represented as percent of control 1 (100\%); mean \pm $S E M ; n=4$

As shown in Fig. 10, the expression level of LONP1/PRSS15 mRNA is increased in control glioma cells (+52\%). Cells with suppressed activity of IRE1 signaling enzyme were resistant to hypoxia. Thus, inhibition of IRE1 removed the effect of hypoxia on this gene expression. We also studied the effect of IRE1 inhibition on the expression of LONP1 gene in normoxic condition. We revealed that inhibition of IRE1 signaling enzyme in glioma cells has slightly decreased the expression level of this gene (-20\%) as compared to control glioma cells (Fig. 10).

Therefore, the effect of hypoxia on the expression level of genes encoding all studied cathepsins as well as mitochondrial lon peptidase 1 is dependent on IRE1 signaling enzyme function, because inhibition of IRE1 significantly modifies hypoxic regulation of these gene expressions: removes the effect of hypoxia on CTSA, and LONPI genes, introduces reverse changes on CTSD and CTSS genes, reduces - on CTSF and CTSK genes, and increases sensitivity to hypoxia of $C T S B$ and CTSL genes (Fig. 11 and 12). Therefore, hypoxia affected the expression level of most studied genes in relation to the functional activity of IRE1 enzyme, a central mediator of endoplasmic reticulum stress, which control cell proliferation and tumor growth.

In this study we have shown that hypoxia significantly affects the expression of most studied genes encoding cathepsins and LONP1 in U87 glioma cells and that inhibition of IRE1 signaling enzyme function modifies the effect of hypoxia on the expression level of these genes in gene specific manner like many other previously studied endoplasmic reticulum stress responsive genes, including nuclear genes for numerous mitochondrial proteins [33, 39, 41-45].

Results of this study clearly demonstrate that the expression of cathepsin $\mathrm{A}$ and $\mathrm{B}$, which have

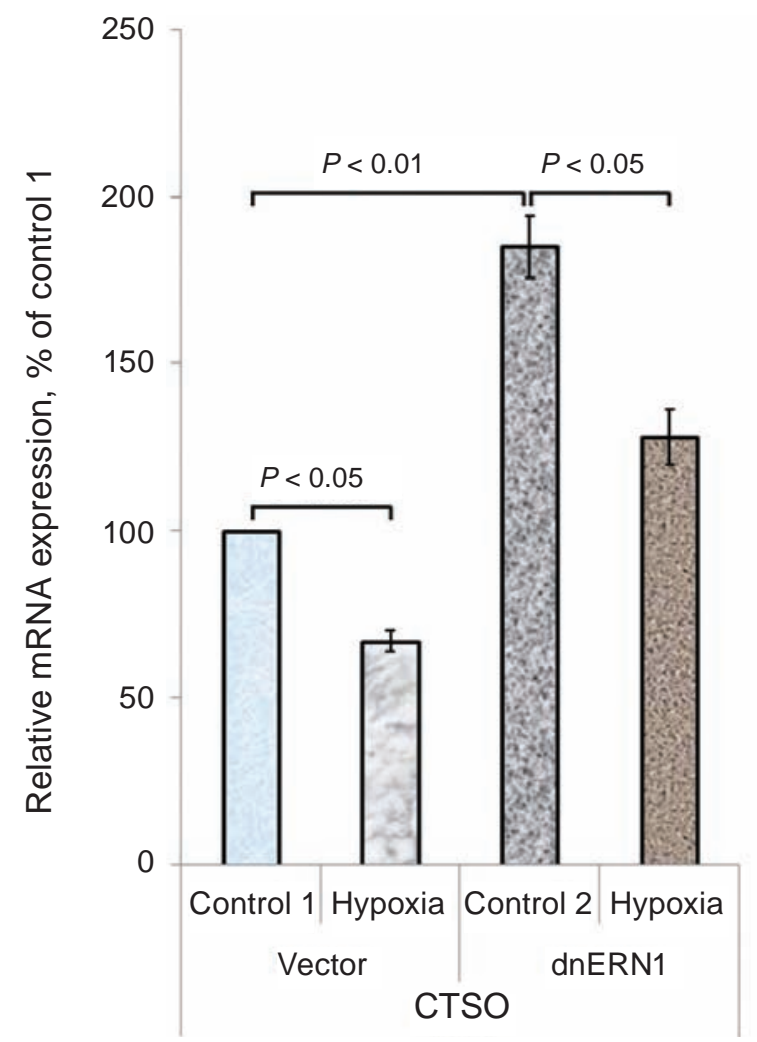

Fig. 8. Effect of hypoxia on the expression level of cathepsin O (CTSO) mRNA in control U87 glioma cells stable transfected with vector (Vector) and cells with inhibited function of signaling enzyme IRE1 (dnIRE1) measured by qPCR. Values of CTSO $\mathrm{mRNA}$ expressions were normalized to $\beta$-actin $m R N A$ and represented as percent of control 1 (100\%); mean \pm SEM; $n=4$ 


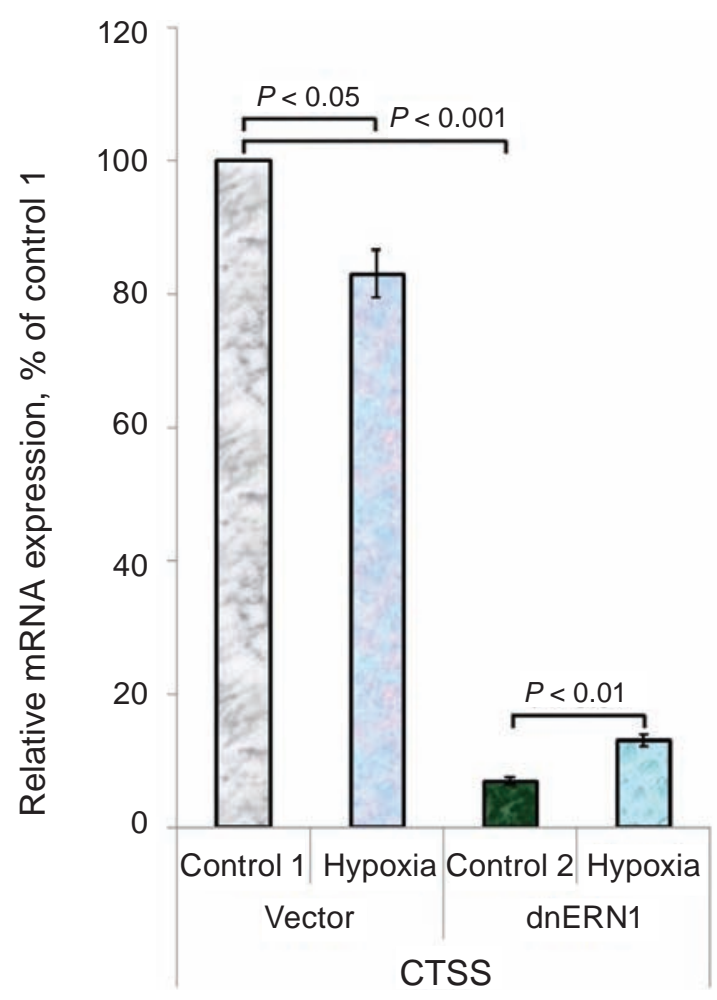

Fig. 9. Effect of hypoxia on the expression level of cathepsin S (CTSS) mRNA in control U87 glioma cells stable transfected with vector (Vector) and cells with inhibited function of signaling enzyme IREI (dnIRE1) measured by qPCR. Values of CTSS mRNA expressions were normalized to $\beta$-actin $m R N A$ and represented as percent of control 1 (100\%); mean \pm $S E M ; n=4$

multiple roles in cancer and autophagy [1, 2, 6, 12], is also increased in control glioma cells upon hypoxia, but the knockdown of IRE1 signaling enzyme in glioma cells removes the sensitivity of CTSA gene expression to hypoxia and enhances this sensitivity for $C T S B$ gene. It is possible that the regulation of $C T S A$ and $C T S B$ genes expression by hypoxia is mediated by IRE1 and blockade of this signaling enzyme function modifies the sensitivity of the expression of these genes to hypoxia. Thus, our results that inhibition of IRE1 via overexpression of dnIRE1 removes the sensitivity of the expression of CTSA gene to hypoxia agree well with functional role of this protease and suppression of glioma cell proliferation $[1,2,5]$. It is interesting to note that overexpression of chaperone protective protein CTSA is associated with the cellular oxidative stress response [5] and involved in tumor progression and metastasis by degrading the extracellular matrix [3, 4]. Hypoxia also induced the expression level of CTSD, CTSF, and CTSK in control glioma cells, but the expression of CTSC, CTSL, CTSO, and CTSS is down-regulated by hypoxia in these glioma cells. At the same time, inhibition of IRE1 had diverse effect on the sensitivity of these genes expression to hypoxia. It is possible that all these cathepsins participate in many pathological conditions and most of them are implicated in tumor invasion, metastasis, and autophagy $[4,15$, 16, 18, 46, 47]. Moreover, almost identical substrate specificities were determined for cysteine cathepsins $\mathrm{K}, \mathrm{L}$ and $\mathrm{S}$, but almost all cathepsins have specific functions and consequently diverse changes upon hypoxia [17, 48].

LONP1 have variable functions and increased level of this gene transcript in control glioma cells upon hypoxia can be responsible for selective degradation of misfolded and certain short-lived regulatory proteins in the mitochondrial matrix, which should be induced by hypoxia [20]. At the same time,

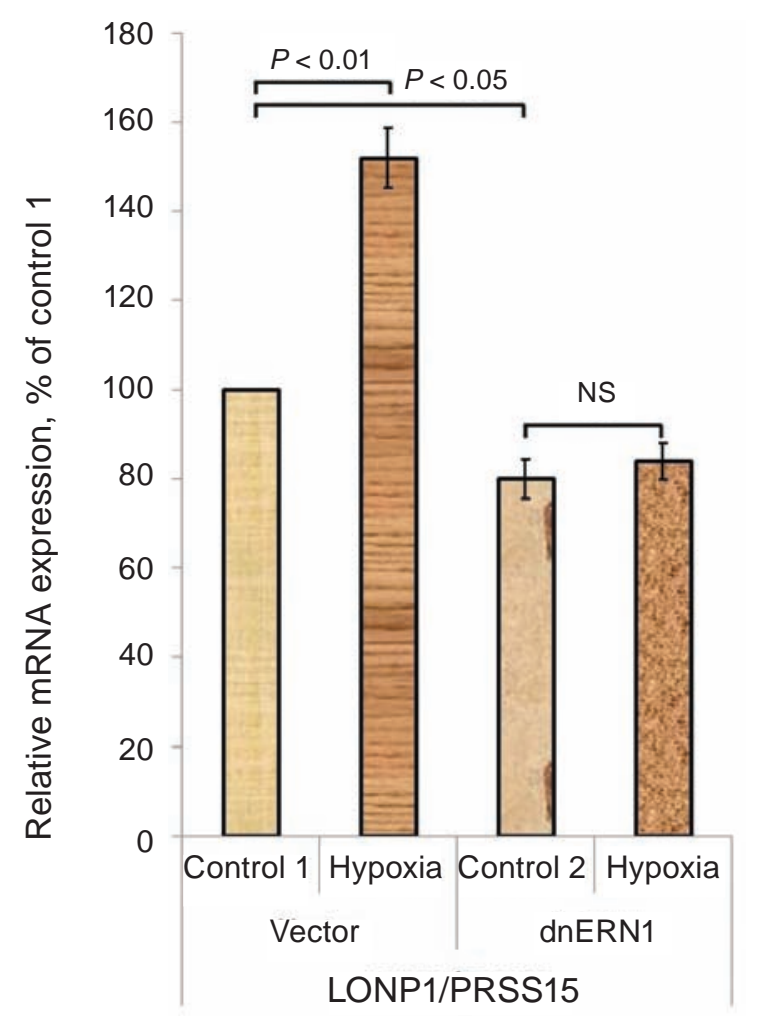

Fig. 10. Effect of hypoxia on the expression level of mitochondrial lon peptidase 1 (LONP1/PRSS15) mRNA in control U87 glioma cells stable transfected with vector (Vector) and cells with inhibited function of signaling enzyme IRE1 (dnIRE1) measured by qPCR. Values of LONPI mRNA expressions were normalized to $\beta$-actin $m R N A$ and represented as percent of control 1 (100\%); mean \pm SEM; $n=4$ 


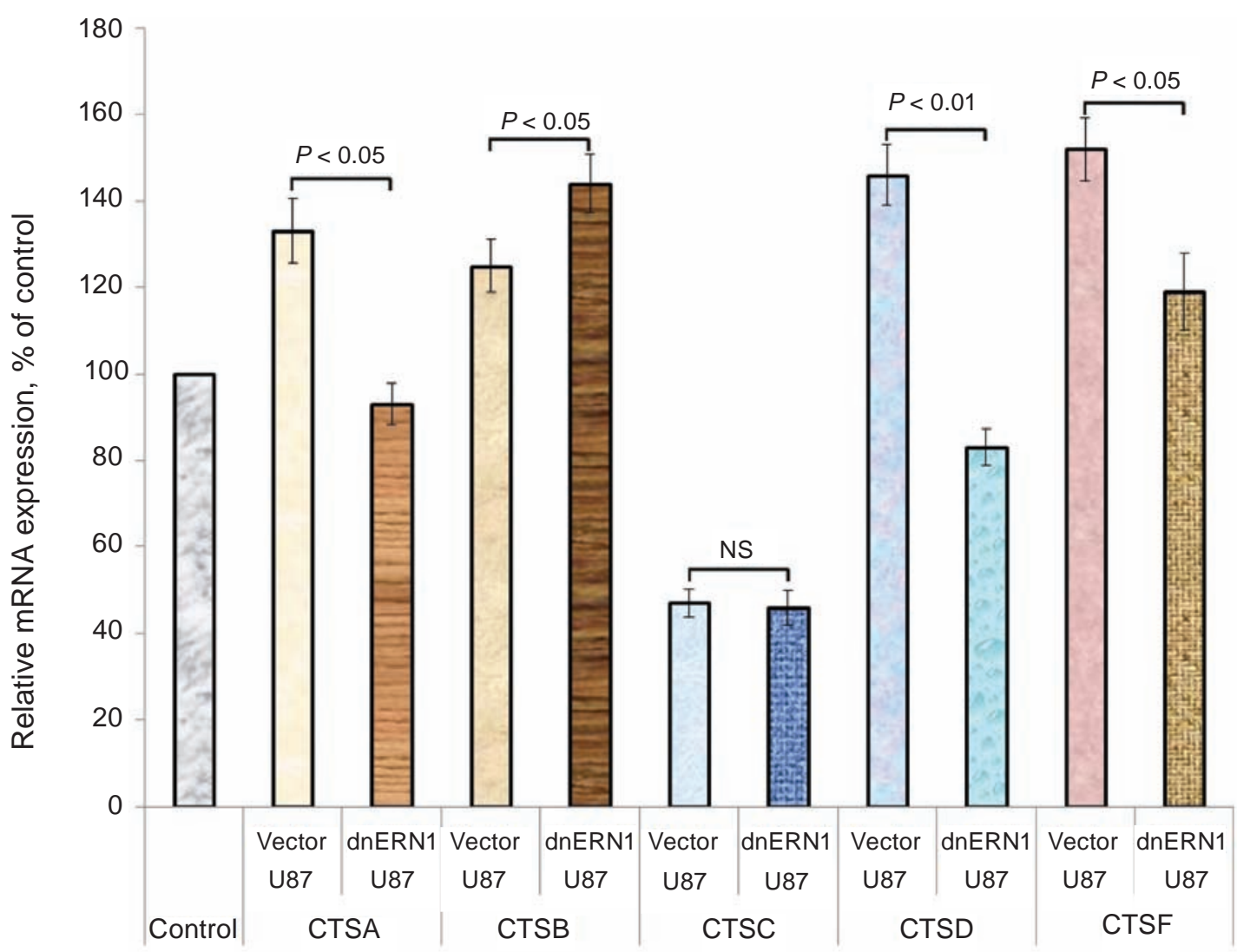

Fig. 11. Effect of hypoxia (3\% oxygen - 16 hrs) on the expression level of LONP1, CTSA, CTSB, CTSC, CTSD, and CTSF mRNA in control U87 glioma cells stable transfected with empty vector (Vector) and in cells without function of signaling enzyme IRE1 (dnIRE1) measured by qPCR. Values of these mRNA expressions were normalized to $\beta$-actin $m R N A$ expression and represented as percent of corresponding control (100\%); mean $\pm S E M ; n=4$

the IRE1 signaling enzyme knockdown in glioma cells completely removes the sensitivity of LONPI gene expression to hypoxia. It is possible that the regulation of this gene expression by hypoxia is mediated by IRE1 and blockade of this signaling enzyme function affects the sensitivity of $L O N P 1$ gene expression to hypoxia. Thus, the increased expression of the LONP1 gene upon hypoxia is agreed well with functional role of this protease [22, 23]. Therefore, LONP1 protease is an essential enzyme for life and plays a critical function in tumorigenesis by regulating the bioenergetics of cancer cells as a central regulator of mitochondrial activity in oncogenesis [20]. Furthermore, the expression of this mitochondrial protease is induced by various stimuli, including hypoxia and reactive oxygen species, and possibly provides protection against cell stress [25].

In conclusion, our results demonstrate that all genes studied are responsive to hypoxia in IRE1 dependent manner and potentially contribute to regulation of cell proliferation, metastasis, and apoptosis through various signaling pathways and stress related transcription, but the mechanisms and functional significance of activation of their expressions through IRE1 inhibition as well as hypoxia are different and warrant further investigation. Thus, the changes observed in the studied genes expression partially agree with slower proliferation rate of glioma cells harboring dnIRE1, attesting to the fact that targeting the unfolded protein response is viable, perspective approach in the development of cancer therapeutics [27, 38, 49-51].

However, the functional significance of changes in LONPI, CTSA, CTSB, CTSC, CTSD, CTSF, CTSK, CTSL, CTSO, and CTSS gene expressions upon hypoxia and inhibition of IRE1 signaling enzyme function is still unclear and more research are needed. 


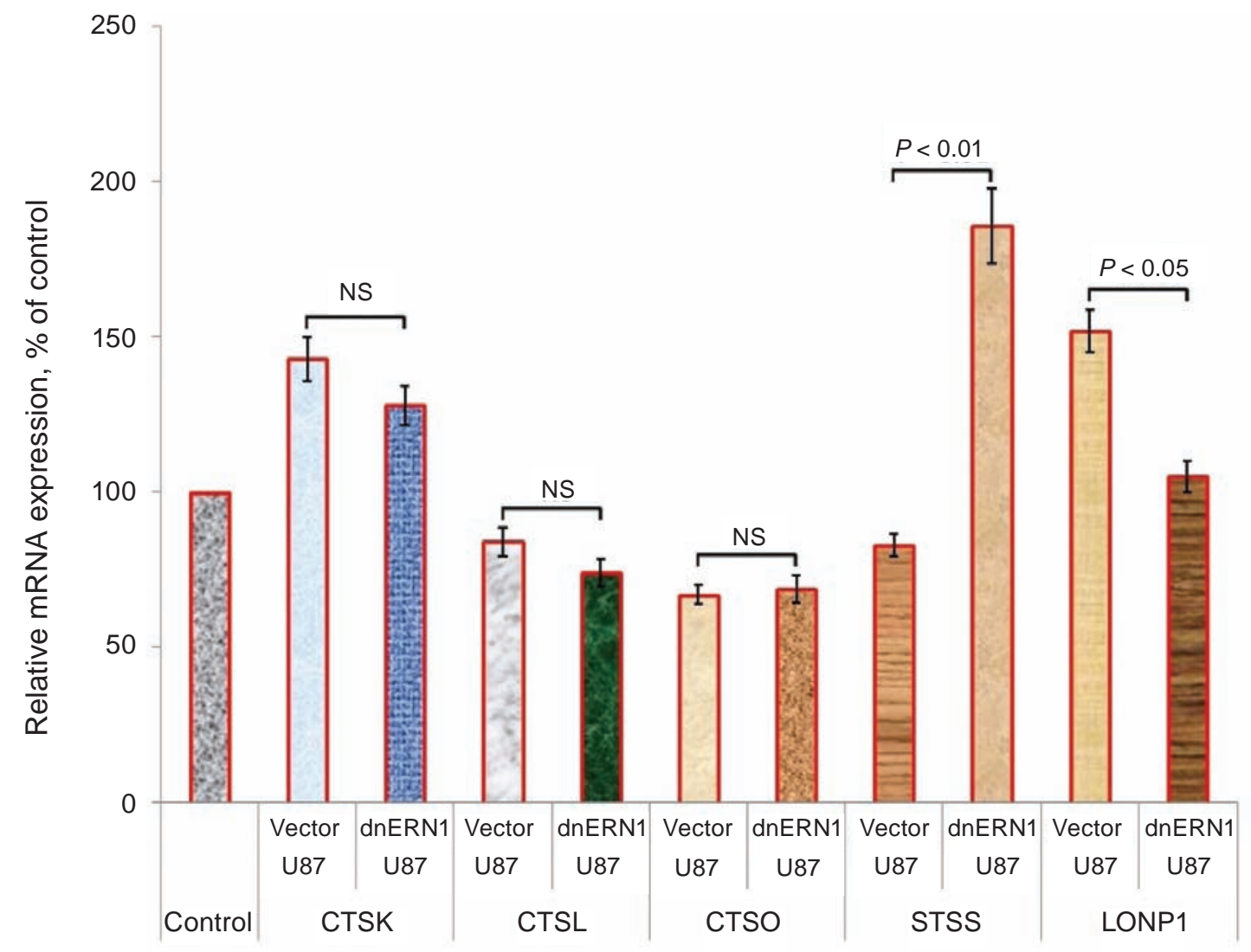

Fig. 12. Effect of hypoxia (\% oxygen - 16 hrs) on the expression level of CTSK, CTSL, CTSO, CTSS, and LONP1 mRNA in control U87 glioma cells stable transfected with empty vector (Vector) and in cells without function of signaling enzyme IRE1 (dnIRE1) measured by qPCR. Values of these $m R N A$ expressions were normalized to $\beta$-actin $m R N A$ expression and represented as percent of corresponding control (100\%); mean $\pm S E M ; n=4$

\section{ПРИГНІЧЕННЯ IRE1 ЗМІНЮЕ ГІПОКСИЧНУ РЕГУЛЯЦЮЮ ЕКСПРЕСІЇ ГЕНІВ КАТЕПСИНІВ ТА LONP1 У КЛІТИНАХ ГЛІОМИ ЛІНІЇ U87}

\section{О. Г. Мінченко, О. О. Рябовол ${ }^{1}$, \\ О. В. Галкін ${ }^{1}$ Д. О. Мінченко, \\ О. О. Ратушна}

\author{
${ }^{1}$ Інститут біохімії ім. О. В. Палладіна \\ НАН України, Київ; \\ e-mail: ominchenko@yahoo.com; \\ ${ }^{2}$ Національний медичний університет \\ ім. О. О. Богомольця, Київ, Україна
}

Вивчено вплив гіпоксії на експресію ядерних генів, що кодують катепсини та LONP1/ PRSS15 у клітинах гліоми лінії U87 в умовах пригнічення залежного від інозитолу ензиму 1 (IRE1). Показано, що гіпоксія збільшувала експресію генів CTSA, CTSB, CTSD, CTSF,
CTSK та LONP1 і знижувала експресію генів CTSC, CTSL, CTSO та CTSS у контрольних (трансфікованих вектором без вставки) клітин гліоми. Пригнічення функції сигнального ензиму IRE1 у цих клітинах змінювало ефект гіпоксії на експресію більшості досліджених генів: знімало ефект гіпоксії на експресію генів CTSA та LONP1, міняло напрям змін на експресію генів CTSD та CTSS, послаблювало на експресію генів CTSF та CTSK і посилювало на експресію генів CTSB та CTSL. Таким чином, гіпоксія змінювала рівень експресії більшості досліджених генів залежно від функціональної активності ензиму IRE1, центрального медіатору стресу ендоплазматичного ретикулума, який контролює проліферацію клітин та ріст пухлин.

Кл ючов і слова: гіпоксія, експресія мPHК, катепсини, LONP1, пригнічення IRE1, клітини гліоми лінії U87. 


\section{УГНЕТЕНИЕ IRE1 МОДИФИЦИРУЕТ \\ ГИПОКСИЧЕСКУЮ РЕГУЛЯЦИЮ ЭКСПРЕССИИ ГЕНОВ \\ КАТЕПСИНОВ И LONP1 В КЛЕТКАХ ГЛИОМЫ ЛИНИИ U87}

О. Г. Минченко ${ }^{1}$, О. О. Рябовол ${ }^{1}$,

О. В. Галкин ${ }^{1}$, Д. О. Минченко ${ }^{1,2}$,

О. О. Ратушна

${ }^{1}$ Институт биохимии им. А. В. Палладина НАН Украины, Киев; e-mail: ominchenko@yahoo.com;

${ }^{2}$ Национальный медицинский университет им. А. А. Богомольца, Киев, Украина

Изучено влияние гипоксии на экспрессию генов, кодирующих катепсины и LONP1/PRSS15 в клетках глиомы линии U87 при угнетении зависимого от инозитола энзима (IRE1). Показано, что гипоксия увеличивала экспрессию генов CTSA, CTSB, CTSD, CTSF, CTSK и LONP1 и снижала экспрессию генов CTSC, CTSL, CTSO и $C T S S$ в контрольных (трансфецированных вектором без вставки) клетках глиомы. Угнетение функции сигнального энзима IRE1 в этих клетках изменяло эффект гипоксии на экспрессию большинства исследованных генов: снимало эффект гипоксии на экспрессию генов CTSA и $L O N P 1$, меняло направление изменений на экспрессию генов CTSD и CTSS, ослабляло - на экспрессию генов CTSF и CTSK и усиливало - на экспрессию генов CTSB и CTSL. Таким образом, гипоксия изменяла уровень экспрессии большинства исследованных генов в зависимости от функциональной активности энзима IRE1, центрального медиатора стресса эндоплазматического ретикулума, который контролирует пролиферацию клеток и рост опухолей.

К л ю ч е в ы е с л о в а: гипоксия, экспрессия мРHK, катепсины, LONP1, угнетение IRE1, клетки глиомы линии U87.

\section{References}

1. Timur ZK, Akyildiz Demir S, Seyrantepe V. Lysosomal Cathepsin A Plays a Significant Role in the Processing of Endogenous Bioactive Peptides. Front Mol Biosci. 2016; 3: 68.

2. Kaminskyy V, Zhivotovsky B. Proteases in autophagy. Biochim Biophys Acta. 2012; 1824(1): 44-50.
3. Haznedaroglu IC, Malkan UY. Local bone marrow renin-angiotensin system in the genesis of leukemia and other malignancies. Eur Rev Med Pharmacol Sci. 2016; 20(19): 4089-4111.

4. Minarowska A, Minarowski Ł, Karwowska A, Milewska AJ, Gacko M. Role of cathepsin A and cathepsin $\mathrm{C}$ in the regulation of glycosidase activity. Folia Histochem Cytobiol. 2012; 50(1): 20-24.

5. Petrera A, Kern U, Linz D, Gomez-Auli A, Hohl M, Gassenhuber J, Sadowski T, Schilling O. Proteomic Profiling of CardiomyocyteSpecific Cathepsin A Overexpression Links Cathepsin A to the Oxidative Stress Response. J Proteome Res. 2016; 15(9): 3188-3195.

6. Aggarwal N, Sloane BF. Cathepsin B: multiple roles in cancer. Proteomics Clin Appl. 2014; 8(56): 427-437.

7. Mitrović A, Kljun J, Sosič I, Gobec S, Turel I, Kos J. Clioquinol-ruthenium complex impairs tumour cell invasion by inhibiting cathepsin B activity. Dalton Trans. 2016; 45(42): 1691316921.

8. Mezawa M, Pinto VI, Kazembe MP, Lee WS, McCulloch CA. Filamin A regulates the organization and remodeling of the pericellular collagen matrix. FASEB J. 2016; 30(10): 36133627.

9. Huber MC, Falkenberg N, Hauck SM, Priller M, Braselmann H, Feuchtinger A, Walch A, Schmitt M, Aubele M. Cyr61 and YB-1 are novel interacting partners of uPAR and elevate the malignancy of triple-negative breast cancer. Oncotarget. 2016; 7(28): 44062-44075.

10. Liu F, Li X, Lu C, Bai A, Bielawski J, Bielawska A, Marshall B, Schoenlein PV, Lebedyeva IO, Liu K. Ceramide activates lysosomal cathepsin $\mathrm{B}$ and cathepsin D to attenuate autophagy and induces ER stress to suppress myeloid-derived suppressor cells. Oncotarget. 2016; 7(51): 8390783925.

11. Jiang Y, Woosley AN, Sivalingam N, Natarajan S, Howe PH. Cathepsin-B-mediated cleavage of Disabled-2 regulates TGF- $\beta$-induced autophagy. Nat Cell Biol. 2016; 18(8): 851-863.

12. Man SM, Kanneganti TD. Regulation of lysosomal dynamics and autophagy by CTSB/ cathepsin B. Autophagy. 2016; 12(12): 25042505.

13. Galluzzi L, Bravo-San Pedro JM, Kroemer G. Autophagy Mediates Tumor Suppression via 
Cellular Senescence. Trends Cell Biol. 2016; 26(1): 1-3.

14. Ruffell B, Affara NI, Cottone L, Junankar S, Johansson M, DeNardo DG, Korets L, Reinheckel T, Sloane BF, Bogyo M, Coussens LM. Cathepsin C is a tissue-specific regulator of squamous carcinogenesis. Genes Dev. 2013; 27(19): 2086-2098.

15. Park YJ, Kim EK, Bae JY, Moon S, Kim J. Human telomerase reverse transcriptase (hTERT) promotes cancer invasion by modulating cathepsin D via early growth response (EGR)-1. Cancer Lett. 2016; 370(2): 222-231.

16. Christensen J, Shastri VP. Matrix-metalloproteinase-9 is cleaved and activated by cathepsin K. BMC Res Notes. 2015; 8: 322.

17. Vizovišek M, Vidmar R, Van Quickelberghe E, Impens F, Andjelković U, Sobotič B, Stoka V, Gevaert K, Turk B, Fonović M. Fast profiling of protease specificity reveals similar substrate specificities for cathepsins $\mathrm{K}, \mathrm{L}$ and $\mathrm{S}$. Proteomics. 2015; 15(14): 2479-2490.

18. Huang CC, Lee CC, Lin HH, Chen MC, Lin CC, Chang JY. Autophagy-Regulated ROS from Xanthine Oxidase Acts as an Early Effector for Triggering Late Mitochondria-Dependent Apoptosis in Cathepsin S-Targeted Tumor Cells. PLoS One. 2015; 10(6): e0128045.

19. Quirós PM, Español Y, Acín-Pérez R, Rodríguez F, Bárcena C, Watanabe K, Calvo E, Loureiro M, Fernández-García MS, Fueyo A, Vázquez J, Enríquez JA, López-Otín C. ATP-dependent Lon protease controls tumor bioenergetics by reprogramming mitochondrial activity. Cell Rep. 2014; 8(2): 542-556.

20. Gibellini L, Pinti M, Bartolomeo R, De Biasi S, Cormio A, Musicco C, Carnevale G, Pecorini S, Nasi M, De Pol A, Cossarizza A. Inhibition of Lon protease by triterpenoids alters mitochondria and is associated to cell death in human cancer cells. Oncotarget. 2015; 6(28): 25466-25483.

21. Kaufman RJ, Malhotra JD. Calcium trafficking integrates endoplasmic reticulum function with mitochondrial bioenergetics. Biochim Biophys Acta. 2014; 1843(10): 2233-2239.

22. Bezawork-Geleta A, Brodie EJ, Dougan DA, Truscott KN. LON is the master protease that protects against protein aggregation in human mitochondria through direct degradation of misfolded proteins. Sci Rep. 2015; 5: 17397.
23. Pinti M, Gibellini L, Nasi M, De Biasi S, Bortolotti CA, Iannone A, Cossarizza A. Emerging role of Lon protease as a master regulator of mitochondrial functions. Biochim Biophys Acta. 2016; 1857(8): 1300-1306.

24. Quirós PM, Bárcena C, López-Otín C. Lon protease: A key enzyme controlling mitochondrial bioenergetics in cancer. Mol Cell Oncol. 2014; 1(4): e968505.

25. Pinti M, Gibellini L, Liu Y, Xu S, Lu B, Cossarizza A. Mitochondrial Lon protease at the crossroads of oxidative stress, ageing and cancer. Cell Mol Life Sci. 2015; 72(24): 4807-4824.

26. Goo HG, Rhim H, Kang S. HtrA2/Omi influences the stability of LON protease 1 and prohibitin, proteins involved in mitochondrial homeostasis. Exp Cell Res. 2014; 328(2): 456465.

27. Auf G, Jabouille A, Guérit S, Pineau R, Delugin M, Bouchecareilh M, Magnin N, Favereaux A, Maitre M, Gaiser T, von Deimling A, Czabanka M, Vajkoczy P, Chevet E, Bikfalvi A, Moenner M. Inositol-requiring enzyme 1alpha is a key regulator of angiogenesis and invasion in malignant glioma. Proc Natl Acad Sci USA. 2010; 107(35): 15553-15558.

28. Malhotra JD, Kaufman RJ. ER stress and its functional link to mitochondria: role in cell survival and death. Cold Spring Harb Perspect Biol. 2011; 3(9): a004424.

29. Pluquet O, Dejeans N, Chevet E. Watching the clock: endoplasmic reticulum-mediated control of circadian rhythms in cancer. Ann Med. 2014; 46(4): 233-243.

30. Hetz C, Chevet E, Harding HP. Targeting the unfolded protein response in disease. Nat Rev Drug Discov. 2013; 12(9): 703-719.

31. Lenihan CR, Taylor CT. The impact of hypoxia on cell death pathways. Biochem Soc Trans. 2013; 41(2): 657-663.

32. Chesney J, Clark J, Klarer AC, ImbertFernandez Y, Lane AN, Telang S. Fructose-2,6bisphosphate synthesis by 6-phosphofructo-2kinase/fructose-2,6-bisphosphatase 4 (PFKFB4) is required for the glycolytic response to hypoxia and tumor growth. Oncotarget. 2014; 5(16): 6670-6686.

33. Minchenko OH, Tsymbal DO, Minchenko DO, Moenner M, Kovalevska OV, Lypova NM. Inhibition of kinase and endoribonuclease 
activity of ERN1/IRE1 $\alpha$ affects expression of proliferationrelated genes in U87 glioma cells. Endoplasm Reticul Stress Dis. 2015; 2(1): 18-29.

34. Manié SN, Lebeau J, Chevet E. Cellular mechanisms of endoplasmic reticulum stress signaling in health and disease. 3. Orchestrating the unfolded protein response in oncogenesis: an update. Am J Physiol Cell Physiol. 2014; 307(10): C901-C907.

35. Colombo SL, Palacios-Callender M, Frakich N, Carcamo S, Kovacs I, Tudzarova S, Moncada S. Molecular basis for the differential use of glucose and glutamine in cell proliferation as revealed by synchronized HeLa cells. Proc Natl Acad Sci USA. 2011; 108(52): 21069-21074.

36. Huber AL, Lebeau J, Guillaumot P, Pétrilli V, Malek M, Chilloux J, Fauvet F, Payen L, Kfoury A, Renno T, Chevet E, Manié SN. p58(IPK)-mediated attenuation of the proapoptotic PERK-CHOP pathway allows malignant progression upon low glucose. Mol Cell. 2013; 49(6): 1049-1059.

37. Tsymbal DO, Minchenko DO, Riabovol OO, Ratushna OO, Minchenko OH. IRE1 knockdown modifies glucose and glutamine deprivation effects on the expression of proliferation related genes in U87 glioma cells. Biotechnologia Acta. 2016; 9(1): 26-37.

38. Auf G, Jabouille A, Delugin M, Guérit S, Pineau R, North S, Platonova N, Maitre M, Favereaux A, Vajkoczy P, Seno M, Bikfalvi A, Minchenko D, Minchenko O, Moenner M. High epiregulin expression in human U87 glioma cells relies on IRE1 $\alpha$ and promotes autocrine growth through EGF receptor. BMC Cancer. 2013; 13: 597.

39. Minchenko DO, Danilovskyi SV, Kryvdiuk IV, Bakalets TV, Lypova NM, Karbovsky LL, Minchenko OH. Inhibition of ERN1 modifies the hypoxic regulation of the expression of TP53related genes in U87 glioma cells. Endoplasm Reticul Stress Dis. 2014; 1: 18-26.

40. Bochkov VN, Philippova M, Oskolkova O, Kadl A, Furnkranz A, Karabeg E, Afonyushkin T, Gruber F, Breuss J, Minchenko A, Mechtcheriakova D, Hohensinner P, Rychli K, Wojta J, Resink T, Erne P, Binder BR, Leitinger N. Oxidized phospholipids stimulate angiogenesis via autocrine mechanisms, implicating a novel role for lipid oxidation in the evolution of atherosclerotic lesions. Circ Res. 2006; 99(8): 900-908.

41. Minchenko DO, Kharkova AP, Karbovskyi LL, Minchenko $\mathrm{OH}$. Expression of insulin-like growth factor binding protein genes and its hypoxic regulation in U87 glioma cells depends on ERN1 mediated signaling pathway of endoplasmic reticulum stress. Endocr Regul. 2015; 49(2): 73-83.

42. Minchenko OH, Tsymbal DO, Minchenko DO, Riabovol OO, Halkin OV, Ratushna OO. IRE$1 \alpha$ regulates expression of ubiquitin specific peptidases during hypoxic response in U87 glioma cells. Endoplasm Reticul Stress Dis. 2016; 3(1): 50-62.

43. Minchenko DO, Riabovol OO, Tsymbal DO, Ratushna OO, Minchenko OH. Inhibition of IRE1 signaling affects the expression of genes encoded glucocorticoid receptor and some related factors and their hypoxic regulation in U87 glioma cells. Endocr Regul. 2016; 50(3): 127-136.

44. Minchenko OH, Tsymbal DO, Minchenko DO, Riabovol OO, Ratushna OO. Hypoxic regulation of the expressions of proliferation related genes in U87 glioma cells upon inhibition of IRE1 signaling. Ukr Biochem. J. 2016; 88(1): 11-21.

45. Minchenko DO, Riabovol OO, Ratushna OO, Minchenko $\mathrm{OH}$. Hypoxic regulation of the expression of genes encoded estrogen related proteins in U87 glioma cells: effect of IRE1 inhibition. Endocr Regul. 2017; 51 (1): 8-19.

46. Zhang W, Wang S, Wang Q, Yang Z, Pan Z, $\mathrm{Li} \mathrm{L}$. Overexpression of cysteine cathepsin $\mathrm{L}$ is a marker of invasion and metastasis in ovarian cancer. Oncol Rep. 2014; 31(3): 1334-1342.

47. Mori J, Tanikawa C, Funauchi Y, Lo PH, Nakamura Y, Matsuda K. Cystatin C as a p53inducible apoptotic mediator that regulates cathepsin L activity. Cancer Sci. 2016; 107(3): 298-306.

48. Sudhan DR, Rabaglino MB, Wood CE, Siemann DW. Cathepsin L in tumor angiogenesis and its therapeutic intervention by the small molecule inhibitor KGP94. Clin Exp Metastasis. 2016; 33(5): 461-473.

49. Wang X, Xiong L, Yu G, Li D, Peng T, Luo D, $\mathrm{Xu}$ J. Cathepsin $\mathrm{S}$ silencing induces apoptosis of human hepatocellular carcinoma cells. $\mathrm{Am} \mathrm{J}$ Transl Res. 2015; 7(1): 100-110. 
50. Backer MV, Backer JM, Chinnaiyan P. Targeting the unfolded protein response in cancer therapy. Methods Enzymol. 2011; 491: 37-56.
51. Johnson GG, White MC, Grimaldi M. Stressed to death: targeting endoplasmic reticulum stress response induced apoptosis in gliomas. Curr Pharm Des. 2011; 17(3): 284-292.

Received 17.02.2017 